\title{
Fast, faster, poorest decisions?: A practical theological exploration of the role of a speedy mobinomic world in decision-making
}

\begin{abstract}
Author:
Jan Albert van den Berg ${ }^{1}$

Affiliation:

${ }^{1}$ Department of Practical Theology, University of the Free State, South Africa

Note:

This article was initially a presentation to the Poverty Symposium 2013, directed by Prof. Dr Johann-Albrecht Meylahn, Department of Practical Theology, Faculty of Theology, University of Pretoria, Pretoria,

South Africa
\end{abstract}

Correspondence to: Jan Albert van den Berg

Email:

vdbergja@ufs.ac.za

Postal address:

PO Box 100985, Brandhof

9324, South Africa

Dates:

Received: 27 Jan. 2014

Accepted: 12 Apr. 2014

Published: 21 July 2014

How to cite this article: Van den Berg, J.A., 2014,

'Fast, faster, poorest decisions?: A practical theological exploration of the role of a speedy mobinomic world in decision-making', HTS Teologiese Studies/ Theological Studies 70(1), Art. \#2615, 5 pages. http:// dx.doi.org/10.4102/hts. v70i1.2615

\section{Copyright:}

(c) 2014. The Authors.

Licensee: AOSIS

OpenJournals. This work

is licensed under the

Creative Commons

Attribution License.

Read online:

口F Scan this $Q R$ code with your smart phone or smart phone or
mobile device to read online.
In a digital world, it seems as if the boundaries between rich and poor are becoming increasingly blurred. A mobinomic world is created through the use of cellular telephones, which plays an important role on multiple levels of socioeconomic understanding. Various advantages are created through the interplay between the power of mobility and the convergence of various forms of media. Considering the immediate accessibility of an overflow of data in various forms as well as time pressure, decision-making is increasingly becoming associated with living in the fast lane of the digital world. Unfortunately, the cost of faster decision-making is that it could potentially result in individuals making poor decisions on various levels. A practical-theological exploration, as embedded in a transversal rational engagement, entails a preliminary investigation and description of this digital reality, especially as portrayed in the dynamics of decision-making associated with the social media platform Twitter.

\section{Introduction}

\section{A multidimensional understanding of poverty}

We are living in a time of continual technological acceleration wherein even the invincible James Bond in the recent film Skyfall (2012) is informed by his assistant - the ingenious character, Q, whose technological expertise is legendary - that 'I can do more damage on my laptop sitting in my pyjamas before my first cup of Earl Grey than you can do in a year in the field'. In contrast to James Bond and his assistant, I do not believe that the discourse of the symposium is thematically focused on the amount of damage that can be caused, but rather - hopefully - on the positive contribution that it can make.

The theme of the symposium, namely 'The shifting identities of the rural, urban and virtual poor: Re-imagining a discourse of reconciliation and social cohesion in South Africa' (Symposium leaflet 2013), already presupposes a multidimensional understanding of poverty. In the title of the symposium, apart from the proverbial (and literal) lack of bread that is prominently associated with material poverty, I also discern transversal accents of rationality on different contexts and nuances of meaning. My own exploration of the overarching theme of poverty falls within the domain of the digital world, in which I follow the trail of decision-making, as nuanced in various forms of poverty and wealth. In my opinion, it is precisely in this pursuit that a contribution can be made to the accommodation of ' $[h]$ armonies, shared insights, unique transversal outcomes' (Symposium leaflet 2013), but '[d]isruptions, contrasts, paradoxes, ironies and deconstructions' (Symposium leaflet 2013) are also accommodated.

\section{What's happening right now?}

Welcome to Twitter. Find out what's happening, right now, with the people and organizations you care about. (http://www.twitter.com/)

Sohaib Athar (@ReallyVirtual) unwittingly sent out a report via Twitter - 10 hours before the first news report appeared - on the military raid conducted by American Special Forces during which Osama bin Laden was killed (Mashable 2013): 'Helicopter hovering above Abbottabad at 1 AM (is a rare event)' (tweet sent on 02 May 2011 at 01:00). This factor in itself comprises a good example of how a microblogging platform such as Twitter is not only becoming a new source of authentic information, but is also challenging the traditional forms of news media in terms of the fastest transmission of the latest news events (Van Dijk 2011:333).

This factor is an expression of a growing digital world in which social media platforms (Facebook and Twitter in particular) play a significant role. This development is further accentuated in the capacity of the social media to rewrite traditional dimensions of spatiality; for example, those of 
a developed and developing world. The consequence hereof is a new domain, including 'the world's largest ungoverned space' (Schmidt \& Cohen 2013:n.p.) leading to an electronic superstate. In this regard, the world-famous Internet psychologist and philosopher, Sherry Turkle, pointed out in her book, Alone together (2011), that what is becoming visible in the growing virtual environment is nothing other 'than the future unfolding' (Turkle 2011:n.p.).

Various examples could be cited of how social media have been instrumental in the recent past in important sociopolitical events. Ironically enough, not only does the most powerful man in the world, President Barack Obama, make use of social media as a primary component of his election campaigns (The European Business Review 2013), but some of the most powerless groupings of people in the world have also had recourse to this media form. The use of Twitter in the facilitation of significant political transitions that would later become known as the Arab Spring is a good example of how the powerful dynamics of social media can empower marginalised societies (Emiroglu 2013). In this regard, Ekine (2010) highlights the following:

The protests following the Iranian elections, the Mumbai bombings and the G20 summit in London, in which mobile phones played a central role in organizing, mobilizing, communicating and disseminating information across the world in real time, show the actual and potential power of citizens journalism in times of crisis. One single message sent by SMS to Twitter can spread throughout the world in minutes. (p. ix)

These factors contain a preliminary indication of the topicality and prominence of the digital field of research. In the endeavour to arrive at a description of a research problem and question, a quest is conducted to find possible links between a digital world and poverty, not only as a multiple phenomenon, but more specifically as a heuristic category and as displayed in decision-making. With the focus falling on the social media platform Twitter as an expression of a growing digital world, the main research question as a further delineation of the research problem could therefore be indicated as follows: how would poverty, although depicted in other terms than just a shortage of bread per se, be manifested in the dynamics of decisionmaking as portrayed on Twitter? In the tracing of possible links in this regard, Müller's (2009:205) development of a 'postfoundational practical theology' provides useful guidance, with the emphasis on a 'way of thinking [that] is always concrete, local, and contextual, but at the same time reaches beyond local contexts to transdisciplinary concerns'.

\section{A speedy mobinomic world}

Hassan (2008:ix) points out that the contemporary world is shaped by at least three interdependent processes, namely:

- neoliberal globalisation

- the information technology revolution

- a phenomenon that arises from the combined effects of the previous two perspectives facilitating a speedier and smaller world.
In terms of the speeding up of time and the shrinking of space, Rushkoff (2013) has recently referred to society's orientation towards:

[T] he present moment. Everything is live, real time, and alwayson. It's not a mere speeding up, however much our lifestyles and technologies have accelerated the rate at which we attempt to do things. (n.p.)

As an expression and example of the acceleration of the pace of life, the transformational mobile device and associated social media platforms can be mentioned; these platforms are facilitated by growing mobile Internet connectivity. The inquiry is therefore contextually defined by the role of mobile connected platforms and their influence on human identity (Lanier 2011:4) and existence (Goggin 2011:181). The cellular telephones, along with dynamic possibilities provided by the use of different forms of social media, have become important drivers of a so-called 'mobinomic world' (Knott-Craig 2012:n.p.). In terms of a mobinomic world, the formation of a virtual ecosystem of connections across various spheres and layers of life by means of mobile platforms is conceptualised and expressed. The role and influence of mobile platforms on human existence is therefore rightfully indicated as an important item on the agenda for discussion (Goggin 2011:181). A possible pivotal point for the interaction between a digital world and human functioning can be found, in my opinion, in the complex field of decisionmaking. It is in the connectedness of this environment that a broader understanding of poverty and wealth is further embodied, on the basis of, inter alia, the interaction between an accelerated digital life and the challenge to the practice of decision-making.

\section{Thinking (and texting) in the fast lane: Tweeting on Twitter}

In an attempt to explore the centrality of decision-making practices in daily life as well as the further actualisations thereof in an accelerated digital world, theoretical perspectives are important. In his recent best-selling book, Thinking fast and slow (2011), Daniel Kahneman, the renowned psychologist who, amongst other accomplishments, won a Nobel Prize in the Economic Sciences category, explains the integrated human thought process as follows:

I describe mental life by the metaphor of two agents, called System 1 and System 2, which respectively produce fast and slow thinking ... I attempt to give a sense of the complexity and richness of automatic and often unconscious processes that underlie intuitive thinking, and how these automatic processes explain the heuristics of judgement. A goal is to introduce a language for thinking and talking about the mind. (n.p.)

Naturally, there is not enough space to even begin to focus on this argumentation with the degree of comprehensiveness that it warrants other than to develop a sensitivity for the architecture of thought processes, heuristic categories and decision-making. However, it is important to place proper emphasis on the role of fast decision-making in a rational scientific environment. 
Practically speaking, it would thus be possible, for example, to formulate a research question focused on tracing the discernible quality (embodiment of poverty or wealth, understood in multiple ways?) of rapid decisions in a mobinomic world. By way of illustration of the relevance and topicality of this research question, Twitter has been selected as an embodiment of the problematic aspects that are being researched. The motivation for this choice is firstly found, inter alia, in the character of Twitter as a social media platform, which is a particularly apt expression of a mobinomic reality. Van Dijk (2011) rightfully points out that:

Twitter users are most likely to access the service through wireless Internet on mobile devices. From the very onset, the platform's intention was to be an open, mobile channel primarily for textual communication. (p. 335)

Owing to the fact that users are thereby given an opportunity to contribute - regardless of location and time - to the development of a moment-by-moment transmission of news, the accentuation of mobility in the character of Twitter is emphasised.

A second reason that can be put forward in motivation of the choice of Twitter as a possible practical expression of rapid decision-making in a digital world is to be found in the significant growth of this platform. White (2012:121) points out that 'Twitter is growing in unprecedented popularity and usage. One only needs to watch the news to hear about Twitter and its present use with the news media'. The interesting facts mentioned above regarding the use of communication technology as well as the remark on the integration between cellular telephone and Internet usage are corroborated by recent media reports focusing on how social media, especially Twitter, are utilised in Africa. Research recently released by Portland Communications shows that $57 \%$ of all African tweets are sent from mobile telephones (Tweetsmarter 2012); South Africa is the country in Africa with the highest number of active users of Twitter (Van den Berg 2012:1 of 6). A recent report by World Wide Worx (2013) on the social media landscape in South Africa has indicated that the user base of Twitter had grown to 2.2 million new users by the end of June 2012, or 100000 new users a month since August 2011.

In this regard, however, a third reason can also be found for the choice of Twitter as the preferred option in the presentation of practical possibilities: the character of Twitter as a medium carries a particular accent in terms of the delivery of comments on factual news events. Not only are personal accents accommodated in this way, but the factual aspects of political and economic news events, inter alia, are also embodied (cf. the reference to the US raid at the beginning of the article). This aspect will later be explored in greater detail by means of some examples of tweets relating to the theme of the conference and, in particular, the topic of this article.

Fourthly and lastly, the choice for the focus on Twitter is motivated by its evolutionary character and the interesting dynamics associated with this specific social media platform (cf. Murthy 2012:1059; Qiu et al. 2012:710; Van Dijk 2011:333). Examples of this richness in dynamics are found in various aspects of the character and functioning of Twitter including the creation of Twitter handles (so-called biodescriptions on Twitter profiles) as well as the question surrounding the identity of those who are followed, as well as followers with their own account.

With the foregoing as a rationale for the choice of a platform, a brief background will now be provided regarding the character and nature of Twitter as a social media platform along with a few examples aimed at expressing the relevance and topicality of the research question.

\section{Tweeting perspectives on Twitter}

Van Dijk (2011) describes the history and development of Twitter. From its initial development by Jack Dorsey in 2006, the social media platform has grown to become one of the most popular platforms of its kind with more than 200 million users who produce more than 110 million tweets per day (Qui et al. 2012:710).

The structure and use of Twitter, which has also been called the 'SMS of the Internet' (Van Dijk 2011:334), can basically be described as the real-time creation, sending and receipt of short messages with a 140 character limit known as 'tweets'. This becomes possible after a Twitter account has been created by going to http://www.twitter.com, after which the user can link with other accounts. In the same way, other persons can then decide to follow the newly-created account. Naturally, the speed and flow of the stream of information is determined by:

... the 'state' of events. If there is a crisis ongoing, obviously more tweets and information will need to be provided. More will be needed and it will be needed at a greater frequency. (White 2012:103)

The research links with precisely this aspect of Twitter wherein the flow of news is embodied at the moment the event takes place in the form of different tweets that are formulated. Owing to the availability of such data, a search can be made for the nuancing of different shades and tones in the expression of decision-making practices. In order to indicate the problematic aspects of so-called rapid decisionmaking in a digital world, and also, at the same time, to describe how such embodiments can indicate a specific understanding of poverty in terms of a social and ethical consciousness, the focus falls on existing examples. There are many examples of how the problematic aspects of such decisions are expressed in practice, and by way of illustration, two examples will suffice.

I have specifically chosen the following examples from the Twitter environment as they represent the characteristics of mobility and speed, and also provide illustrations of arguably poor decision-making in a particularly striking way: 
- The first example is documented by Schmidt and Cohen from Google in their new book, The digital age (2013), dealing with the young Saudi columnist, Hamza Kashgari, who posted an imaginary conversation with the prophet Mohammed on his personal Twitter account in February 2012: 'I have loved aspects of you, hated others, and could not understand many more' (Schmidt \& Cohen 2013:n.p.). This immediately gave rise to public outrage, resulting in the creation of a Facebook page entitled, 'The Saudi people Demand Hamza Kashgari's Execution', and despite the fact that he removed the offending entries within six hours, he is currently still in custody and his fate is uncertain.

- A second example is documented by Foot (2013:202) in his reference to the usage of Twitter for the purpose of making racist utterances, which recently landed two young fashion models in serious trouble. Early in May 2012, the FHM model of the year 2011, Jessica Leandra dos Santos, set the world abuzz through a tweet that read as follows: 'Just, well took on an arrogant and disrespectful $\mathrm{k}^{* * * *} \mathrm{r}$ inside Spar. Should have punched him, should have [sic]' (John 2012). According to other sources, she had previously tweeted a similar message: 'Highlight of my weekend? Almost punching an arrogant and disrespectful \#Engen petrol assistant. No tolerance for rude African monkeys whatsoever!' (Mnguni 2012). It was not long before the reactions were forthcoming. Another model, Tshidi Thamana, responded as follows: 'Dear Mr Peter Mokaba ... I wish All White People were killed when you sang "Kill the Boer" we wouldn't be experiencing @JessicaLeanda's racism right now *:-; (Foot 2013:302). Fortunately, the two models later made peace; nevertheless, this illustrates the problematic aspects of the rapid (and ethically poor?) decision-making that can take shape on a social platform. Naturally, the concerned example also holds particular implications for the endeavour to '[re-imagine] a discourse of reconciliation and social cohesion in South Africa' (Symposium leaflet 2013).

In conclusion, possible perspectives for a practical theological involvement in the decision-making practices of a digital world will be considered next. In the tracing of alternative possibilities, a positive example from the Twitter environment will also be indicated.

\section{Conclusion}

\section{Pointing (thinking?) beyond - A practical theological exploration}

The growing interdisciplinary study of religion and the Internet during the past few years has highlighted the understanding that new media have become embedded in our everyday lives, and are a common platform for spiritual engagement (Campbell 2011:10). Acknowledging this reality, practical theology $y^{1}$ aims to investigate this practice empirically and to interpret it to construct a theological

1 Practical theology is a term commonly used in Christian theology for a general way of doing theology concerned with the embodiment of religious belief in the day-today lives of individuals and communities' (Miller-McLemore 2012:n.p.). framework within which it can be critically assessed by providing models of practice ${ }^{2}$ for future conduct and reform (Osmer 2006:329). From the assumption that practical theology entails the study of practices of 'lived religion' (Ganzevoort 2009:n.p.), the importance of interdisciplinary reflection is taken as a given factor. In the act of considering and reflecting on the foregoing, the practical theological endeavour to '[trace] the sacred' in the 'hermeneutics of lived religion' is given shape (Ganzevoort 2009:n.p.).

In my opinion, a possible practical-theological description of, and contribution to, this challenge can be found in an interdisciplinary method of research; for example, that of transversal rationality, which places emphasis on contextual realities in such a way that a contribution can be made to a larger discourse (Müller 2009:205). This orientation towards a particular modus operandi indeed facilitates practical theological alternatives (Müller 2011:5 of 5) in which the horizons of understanding and practice are broadened. On the basis of this practical theological orientation, I would like to put forward an argument advocating the acknowledgement of the 'shifting identities of the ... virtual poor' (Symposium leaflet 2013). By way of background information regarding these 'shifting identities', reference can be made to the so-called digital divide, wherein the difference between developed countries (e.g. Iceland, Norway and Holland) that benefit from a rich Internet availability, and developing countries that have poor Internet availability (e.g. East Timor and Myanmar) (Green 2010:65). The implication of this distinction is that it confirms, inter alia, that 'many nations suffer from being on the wrong side of the digital divide and this lack of e-knowledge and infrastructure has implications for their economy and their society' (Green 2010:65-68). The reference to the digital divide is made, in the first place, to indicate that access to the digital world like many other commodities is also mapped out in monetary terms. However, as will be argued in the following paragraph, the phenomenal growth of cellular telephones used by rich and poor alike around the world is shrinking this divide, making access to the Internet much easier, and bringing it within the reach of people from all walks of life.

Ironically enough, and with due consideration of the emphasis, arising from a 'postfoundational practical theology' on the orientation that aims to 'reach beyond local contexts' (Müller 2009:205), an ever-increasing variety of alternatives within the context of the distinction between the poor and the wealthy are already being mapped out in a digital world. In all probability, the prominent driving force behind these alternatives is characterised by the increasing use of cellular telephones, regardless of one's material status. The relevance of this indication is indeed reflected in the findings of the well-known biennial Ipsos-Markinor study (2012): 'If South Africa were a village ... what would it look like?' In this study, it was found that out of '100 people

2.1 concur with MacIntyre (1981:187) and Dykstra and Bass (2002:22), who regard 'practice' as any coherent, complex, sustained, cooperative pattern of human activity, pertaining to some fundamental feature of existence, such as specific needs and conditions, which is carried out systematically over a period of time (Van den Berg 2012:2 of 6). 
in South Africa who were interviewed, 83 people own, rent or use a cell phone' (Ipsos 2012:n.p.). This indication and the possibilities that are presented by the availability of such a large number of cellular telephones are indeed of importance in the facilitation of a practical theological inquiry. Questions regarding the use of cellular telephones as a positive contribution at both individual and collective levels, to the accommodation of positive and sustainable digital heuristic categories (e.g. decision-making practices) with a view to the facilitation of the 'shifting identities of the ... virtual poor' (Symposium leaflet 2013), can then be formulated. In this way, an involvement in a mobinomic world is expressed, but a relevant practical theology is also facilitated with a view to the articulation of accountable perspectives for life in a digital world.

In order to give expression, on the one hand, to the use of cellular telephones, but also, on the other hand, to the more significant possibilities that are offered by the digital world in the form of the Internet, the following example can be mentioned: 'tech-savvy' Francis Kariuki (aged 47), the administrative chief of Lanet Umoja, used Twitter as a crimefighting tool but also to send messages of hope and peace (The Telegraph 20 February 2012). Kariuki has managed to overcome the divide between cellular telephone and Internet usage, as discussed above, providing access to tweets by making use of a third-party mobile phone application. Although Kariuki's official Twitter page shows 300 followers, it is estimated that a high percentage of the 28000 residents in the area receive messages that are directly and indirectly sent out by him. It therefore becomes clear how a digital message, as embodied in a tweet, can attain 'viral' status. White (2012) provides an apt summary by pointing out that:

Viral just means that they spread or have the potential to spread with an enormous capacity given the number of people following you and others who may re-tweet the information or message. (p. 108)

In my view, this example offers a description that can accommodate some of the most important accents of a postfoundational practical theology acknowledging the possibility of multilayered descriptions of a 'lived [digital?] religion' (Ganzevoort 2009:n.p.). Within this space, focused questions can be accommodated pertaining to the possible role and meaning of spirituality (or spiritualities), the facilitation of behavioural patterns (habitus), as well as the further concretisation of practical wisdom in the daily practice of decision-making in a digital world.

\section{Acknowledgments}

\section{Competing interests}

The author declares that he has no financial or personal relationship(s) that may have inappropriately influenced him in writing this article.

\section{References}

Campbell, H.A., 2011, When religion meets new media, Routledge, London.
Dykstra, C. \& Bass, D.C., 2002, 'A theological understanding of Christian Practices', in M.V. Bass \& D.C. Bass (eds.), Practicing theology: Beliefs and practices in Christian life, pp. 13-32, William B. Eerdmans Publishing Company, Grand Rapids.

Ekine, S., 2010, 'Introduction', in S. Ekine (ed.), SMS uprising: Mobile activism in Africa, pp. ix-xxii, Pambazuka Press, Cape Town.

Emiroglu, S., 2013, The role of social media in Arab spring, viewed 16 July 2013, from http://www.academia.edu/2578601/The_Role_of_Social_Media_in_Arab_Spring

Foot, L., 2013, 'Living beyond apartheid: Narratives of church members from a longitudinal pastoral involvement', PhD thesis, Department of Practical Theology, University of the Free State.

Ganzevoort, R.R., 2009, 'Forks in the road when tracing the sacred: Practical theology as hermeneutics of lived religion', Presidential address to the 9th conference of the International Academy of Practical Theology, Chicago, United States of America, August 03, 2009, viewed 24 April 2010, from http://www.ruardganzevoort.nl/ pdf/2009_Presidential.pdf

Goggin, G., 2011, Global mobile media, Routledge, London.

Green, L., 2010, The internet: An introduction to new media, Berg Publishers, Oxford.

Hassan, R., 2008, The information society: Digital media and society series, Polity Press, Cambridge.

Ipsos, 2012, If South Africa was a village ... What would it look like?, viewed 28 April 2012, from http://www.ipsos.co.za/SitePages/lf\%20South\%20Africa\%20was\%20 a\%20village.aspx

John, V., 2012, 'Heads roll as racism boils over on Facebook and Twitter', Mail \& Guardian, viewed 13 May 2012, from http://mg.co.za/article/2012-05-10-heads-roll-as-racismboils-over-on-facebook-and-twitter/

Kahneman, D., 2011, Thinking fast and slow, Penguin London. (Kindle edn.).

Knott-Craig, A., 2012, 'Mobinomics, Mxit and Africa's mobile revolution', Bookstorm, Johannesburg. (Kindle edn.).

Lanier, J., 2011, You are not a gadget, Vintage Books, New York.

MacIntyre, A., 1981, After virtue, 2nd edn., University of Notre Dame Press, Notre Dame.

Mashable, 2013, One Twitter user reports live from Osama Bin Laden raid, viewed 15 June 2013, from http://mashable.com/2011/05/01/live-tweet-bin-laden-raid/

Miller-McLemore, B.J., 2012, Christian theology in practice: Discovering a discipline, William B. Eerdmans Publishing Company, Grand Rapids. (Kindle edn.).

Mnguni, L., 2012, 'The big read: Beyond mere tolerance', Times Live, viewed 16 June 2012, from http://www.timeslive.co.za/opinion/commentary/2012/05/08/the-bigreadbeyond-mere-tolerance

Murthy, D., 2012, 'Towards a sociological understanding of social media: Theorizing Twitter', Sociology 46(6), 1059-1073. http://dx.doi.org/10.1177/0038038511422553

Müller, J., 2009, 'Transversal rationality as a practical way of doing interdisciplinary work with HIV and Aids as a case study', Practical Theology in South Africa 24(2), 199-228.

Müller, J.C., 2011, 'Postfoundational practical theology for a time of transition', HTS Teologiese Studies/Theological Studies 67(1), Art. \#837, 5 pages. http://dx.doi. org/10.4102/hts.v67i1.837

Osmer, R.R., 2006, 'Toward a transversal model for interdisciplinary thinking in practical theology', in L.R. Shults (ed.), The evolution of rationality: Interdisciplinary essays in honor of J. Wentzel van Huyssteen, pp. 327-345, William B. Eerdmans Publishing Company, Grand Rapids.

Rushkoff, D., 2013, Present shock: When everything happens now, Penguin Group, New York. (Kindle edn.).

Qiu, L., Lin, H., Ramsay, J. \& Yang, F., 2012, 'You are what you tweet: Personality expression and perception on Twitter', Journal of Research in Personality 46, 710-718. http:// dx.doi.org/10.1016/j.jp.2012.08.008

Schmidt, E. \& Cohen, J., 2013, The new digital age: Reshaping the future of people, nations and business, John Murray, London. (Kindle edn.)

Skyfall, 2012, motion picture, Eon Productions, MGM and Sony Pictures Entertainment, Culver City, CA, viewed 21 June 2013, from http://www.imdb.com/title/tt1074638/ quotes

Symposium leaflet, 2013, The shifting identities of the rural, urban and virtual poor: Reimagining a discourse of reconciliation and social cohesion in South Africa, 07-08 August 2013, Faculty of Theology, University of Pretoria.

The European Business Review, 2013, Obama and the power of social media and technology, viewed 16 July 2013, from http://faculty-gsb.stanford.edu/aaker/pages/ documents/TEBRMay-June-Obama.pdf

“'Help sheep missing": How Twitter is fighting crime in Kenya', The Telegraph, 2012, viewed 14 June 2012, from http://www.telegraph.co.uk/technology/ twitter/9092988/Twitter-Chief-Kariuki-fights-crime-in-Kenya.htm

Turkle, S., 2011, Alone together: Why we expect more from technology and less from each other, Basic Books New York. (Kindle edn.).

Tweetsmarter, 2012, First map of Twitter use in Africa, viewed 14 June 2012, from http:// blog.tweetsmarter.com/twitter-stats/first-map-of-twitter-use-in-africa/

Twitter, 2013, viewed 22 May 2013 at https://twitter.com

Van den Berg, J-A., 2012, 'Theoretical signposts for tracing spirituality within the fluid decision-making of a mobile virtual reality', HTS Teologiese Studies/Theological decision-making of a mobile virtual reality', HTS Teologiese Studies/Theolog
Studies 68(2), Art. \#1290, 6 pages. http://dx.doi.org/10.4102/hts.v68i2.1290

Van Dijk, J., 2011, 'Tracing Twitter: The rise of a micro blogging platform', International Journal of Media and Cultural Politics 7(3), 333-348. http://dx.doi.org/10.1386/ macp.7.3.333_1

White, C.M., 2012, Social media, crisis communication, and emergency management: Leveraging Web 2.0 technologies, CRC Press, New York.

World Wide Worx, 2013, South African social media landscape 2012, viewed 12 September 2013, from http://www.worldwideworx.com/wp-content/uploads/2012/10/ExecSummary-Social-Media-20121.pdf 